\title{
Philosophiques
}

\section{La critique herméneutique de l'épistémologie chez Charles Taylor}

\section{Guillaume St-Laurent}

Volume 41, numéro 1, printemps 2014

URI : https://id.erudit.org/iderudit/1025724ar

DOI : https://doi.org/10.7202/1025724ar

Aller au sommaire du numéro

\section{Éditeur(s)}

Société de philosophie du Québec

\section{ISSN}

0316-2923 (imprimé)

1492-1391 (numérique)

Découvrir la revue

Citer cet article

St-Laurent, G. (2014). La critique herméneutique de l'épistémologie chez

Charles Taylor. Philosophiques, 41(1), 79-103. https://doi.org/10.7202/1025724ar
Résumé de l'article

Le projet philosophique central de Charles Taylor se présente comme une critique de l'" image épistémologique " (epistemological picture) de la raison, critique qui se déploie au nom d'une compréhension de la rationalité humaine plus sensible à sa finitude transcendantale et historique. L'objectif du présent essai consiste à présenter une brève analyse comparative de cette image épistémologique (ou post-cartésienne) ainsi que de la perspective herméneutique que lui oppose notre auteur. En ce sens, nous comparerons tour à tour six aspects déterminants de ces deux conceptions : le caractère " apodictique », " médiationnel ", " désengagé ", " désignatif ", " dépassionné " et " procédural » de la première et le caractère " ad hominem ", " immergé ", « situé », « expressif », " passionné » et " substantiel » de la seconde. Nous éclairerons en outre les enjeux complexes de cette critique par quelques remarques introductives et conclusives. 


\title{
La critique herméneutique de l'épistémologie chez Charles Taylor
}

\author{
GUILLAUME ST-LAURENT \\ guil.stlaurent@gmail.com \\ Université de Montréal
}

\begin{abstract}
RÉSUMÉ. - Le projet philosophique central de Charles Taylor se présente comme une critique de l'«image épistémologique» (epistemological picture) de la raison, critique qui se déploie au nom d'une compréhension de la rationalité humaine plus sensible à sa finitude transcendantale et historique. L'objectif du présent essai consiste à présenter une brève analyse comparative de cette image épistémologique (ou post-cartésienne) ainsi que de la perspective herméneutique que lui oppose notre auteur. En ce sens, nous comparerons tour à tour six aspects déterminants de ces deux conceptions: le caractère «apodictique », «médiationnel», «désengagé », «désignatif», «dépassionné» et «procédural» de la première et le caractère «ad hominem», «immergé», «situé», «expressif», «passionné» et «substantiel» de la seconde. Nous éclairerons en outre les enjeux complexes de cette critique par quelques remarques introductives et conclusives.
\end{abstract}

\begin{abstract}
Charles Taylor's main philosophical project presents itself as a critique of the "epistemological picture" of rationality. This critique is put forward in the name of a new understanding of reason, more sensitive to its transcendental and historical finitude. We herein propose a short comparative analysis of this epistemological (or post-cartesian) picture and Taylor's hermeneutical perspective. To this effect, we will compare six essential aspects of these two conceptions: the "apodictic", "mediational", "disengaged", "designative", "dispassionate", and "procedural" character of the former, and the "ad hominem", "immerged", "situated", "expressive", "passionate", and "substantial" character of the latter. We will also try to shed light on these complex issues by some introductive and conclusive remarks.
\end{abstract}

Le projet philosophique central de Charles Taylor se présente comme une critique de l' "image épistémologique » (epistemological picture) de la raison, critique qui se déploie au nom d'une compréhension de la rationalité humaine plus sensible à sa finitude transcendantale et historique. Véritable «hydre» dont "les têtes serpentines font des ravages dans l'ensemble de la culture intellectuelle de la modernité » ${ }^{1}$, l'épistémologie post-cartésienne est ici entendue comme un système de présuppositions plus ou moins explicites dont demeurerait captive, à plusieurs égards, la réflexion philosophique contemporaine:

My reason is that you don't just walk away from these deep, pervasive, halfarticulated, taken-for-granted pictures that are embedded in our culture and

1. Charles Taylor, «Preface», I995, p. vii (notre traduction). 
enframe our thought and action. "A picture held us captive", as Wittgenstein put it. You can't free yourself from them until you identify them and see here they're wrong, and even then it's not always easy. Just saying you've abandoned them, and then not giving them any further thought, à la Davidson, is a sure recipe for remaining in their thrall. ${ }^{2}$

L'objectif du présent essai consiste à présenter une brève analyse comparative de la raison épistémologique ainsi que de la perspective herméneutique que lui oppose notre auteur. En ce sens, nous comparerons tour à tour six aspects déterminants de ces dernières, à savoir le caractère "apodictique », «médiationnel », "désengagé », "désignatif», "dépassionné » et "procédural» de la conception épistémologique, d'une part, et le caractère "ad hominem », "immergé ", " situé », "expressif », " passionné » et "substantiel» de sa conception herméneutique, d'autre part. Notre pari est que ces distinctions permettront, non seulement de brosser un portrait global de la position de Taylor et de mieux situer cette dernière au sein de la tradition herméneutique contemporaine, mais également et avant tout de faire ressortir des enjeux décisifs que nous gagnerions à débattre de façon plus directe et nuancée.

\section{Remarques introductives}

Trois remarques introductives nous paraissent indispensables avant d'entrer dans le vif du sujet. En premier lieu, il convient de souligner que Taylor situe expressément l'émergence de la raison épistémologique dans le contexte de l'effondrement de l'ontologie antico-médiévale des "formes intelligibles": "[...] the idea that the reality around us is what it is by virtue of being shaped by $I d e a s^{3}$ ". À cet effet, celui-ci discute principalement (i) de la révolution nominaliste, dont l'enjeu central fut le rejet de l'essentialisme au nom de l'omnipotence divine ${ }^{4}$, (ii) de l'essor des sciences empiriques ${ }^{5}$, (iii) de la mécanisation de la nature ${ }^{6}$ ainsi que (iv) du désenchantement (Entzauberung) du monde vécu par l'affermissement progressif d'une frontière nette entre le monde objectif-extérieur et le domaine subjectif-intérieur de notre vie psychique ${ }^{7}$. Prises conjointement, ces conditions d'émergence de la raison moderne permettraient de comprendre à la fois son influence durable et comment elle put apparaître comme l'unique solution de remplacement viable à la conception participative et contemplative qui prévalait au sein de la tradition métaphysique classique.

2. Charles Taylor, «Rorty and Philosophy», 2003, p. I 58 -I 59.

3. Charles Taylor, "Retrieving Realism», 20I3, p. 73.

4. Charles Taylor (I980), "Language and Human Nature», I98 5a, p. 222-225.

5. CharlesTaylor (I982), "Rationality », I985b, p. I42-I 50.

6. Charles Taylor, I989, p. I44-I47, I60-I64; 2007, p. 95-99.

7. Notre auteur parle en ce sens de la transition d'un «moi poreux» (porous self) à un «moi calfeutré » (buffered self). Charles Taylor, 2007, p. 29-4I. 
En second lieu, l'originalité et l'intérêt des analyses de Taylor tiennent notamment à son interprétation des "sources morales" du cartésianisme, qui plonge ses racines à la fois dans le vaste tournant historique de la chrétienté vers l' "intériorité ${ }^{8}$ ainsi que dans l'humanisme de la Renaissance et son idéal d'une "seconde création" par la raison et l'imagination". En ce sens, notre auteur soutient que l'image épistémologique qui nous intéresse ici fut elle-même l'expression, sur le plan théorique, de l'aspiration à la mâेtrise instrumentale de soi et du monde qui animait le néo-stö̈cisme de la fin du $\mathrm{XVI}^{\mathrm{e}}$ siècle. Cet idéal est alors compris comme une intériorisation de l'éthique de l'honneur guerrier où le contrôle rationnel et "désengagé » s'accompagne d'un sentiment intime de force, de liberté et de dignité ${ }^{10}$. Dans une perspective plus ample encore, explorée en détail dans les premiers chapitres de A Secular Age (2007), notre auteur relève les liens étroits entre cette "posture instrumentale» (instrumental stance) et ce qu'il dépeint comme le colossal "travail de la Réforme" (the work of Reform), dont le but avoué était " [...] d'en finir avec un christianisme à plusieurs vitesses ${ }^{11}$ ».

Notre troisième et dernière remarque concerne l'importance de la problématique post-kantienne des "arrière-plans" (background conditions) de l'expérience humaine chez Taylor, c'est-à-dire des relations de "sens " (significance, Sinn) en vertu desquelles une chose peut être chaque fois comprise en tant que telle ou telle: "[...] for something to be intelligibly $X$ is for it to count as intelligibly $X$, and there are always contextual conditions for any-

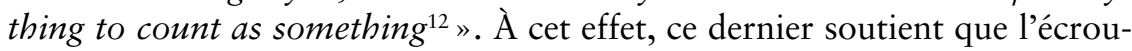
lement de l'ontologie des Idées, et plus spécifiquement de ses variantes aristotélicienne-thomistes, rendit proprement inévitable la question des "conditions de l'intentionnalité » — à la manière d'une brèche ontologique que la tradition épistémologique se serait efforcée, en vain, de colmater ${ }^{13}$. La thèse principale de notre auteur est que les arrière-plans, et en particulier les

8. Cf. Charles Taylor, I989, deuxième partie («Inwardness »).

9. Cf. Charles Taylor, 2007, chapitre II.

10. "The ethic of rational control, finding its sources in a sense of dignity and selfesteem, transposes inward something of the spirit of the honour ethic. No longer are we winning fame in public space; we act to maintain our sense of worth in our own eye. " (Charles Taylor, I989, p. I52).

11. Charles Taylor, «Précis de Modern Social Imaginaries ", 2006, p. 479. En ce sens, le «Grand récit de la Réforme " (Reform Master Narrative) proposé par Taylor décrit notamment le processus au sein duquel se consolidèrent du $\mathrm{Xv}^{\mathrm{e}}$ au $\mathrm{XVII}^{\mathrm{e}}$ siècle les objectifs de la "civilité " (paix domestique, discipline et éducation) et ceux des réformes religieuses (dévotion plus intense, personnelle et intérieure). Ces nouvelles normes éthico-spirituelles impliquèrent toutes à leur manière une posture de reconstruction ou d' "auto-façonnement" (self-fashioning) à l'égard de soi, de la société et du monde. Cf. Charles Taylor, 2007, p. I03-105.

12. Charles Taylor (I99I), "Lichtung or Lebensform: Parallels between Heidegger and Wittgenstein", I995, p. 72.

13. "It takes an insensitivity, which is largely generated and legitimated by the epistemological tradition, to avoid raising it» (Charles Taylor, I995, p. 290, n. I 5). 
conditions "transcendantales » ou «indispensables » de l'expérience, constituent la tache aveugle décisive de la raison post-cartésienne ainsi que le levier permettant de la renverser (ou de la "déconstruire »): "We argue the inadequacy of the epistemological construal, and the necessity of a new conception, from what we show to be indispensable conditions of there being anything like experience or awareness of the world in the first place ${ }^{14}$." En ce sens, Taylor se réclame explicitement de l'«herméneutique postheideggérienne» et défend une conception de la raison arc-boutée sur l'idée que l'être humain est «un animal langagier qui s'auto-interprète» (a selfinterpreting animal), dont l'existence est façonnée en profondeur par la manière dont il se comprend et auquel incombe, par conséquent, la responsabilité de son être ${ }^{15}$.

\section{Raison «apodictique» et raison «ad hominem »}

On le sait, la révolution épistémologique opérée par Descartes consista à montrer que toute connaissance devait obéir à un double mouvement de fondation et de (re) construction méthodique: "Foundationalism involves the double move, stripping down to the unchallengeable, and building back up ${ }^{16}$.» Comme nous le mentionnions à l'instant, Taylor soutient que cette révolution devrait être comprise dans le contexte d'un "stoïcisme christianisé ", mu par un idéal de maîtrise rationnelle, de liberté et de responsabilité de soi. Il met également en relief la rupture marquée par le fondationnalisme épistémologique au sein de la grande tradition sceptique, alors que le doute devint la préparation indispensable à toute philosophie plutôt que d'avoir pour rôle de conduire, par la reconnaissance de la "force égale des choses»(isostenia), à la "suspension du jugement» (épokê tês diánoias) et l'ataraxie ${ }^{17}$.

Ainsi, la procédure cartésienne au cœur du rationalisme et de l'empirisme modernes enjoint à penser toute connaissance comme intuition apodictique (rationnelle ou sensible), apte à résister à un "doute général et universel », puis comme l'expansion ou la culture méthodique (déductive ou inductive), progressive et idéalement exempte de révision, de ces intuitions premières et atomiques ${ }^{18}$. Toutefois, au-delà du fondationnalisme stricto sensu et en des termes valables tant pour la rationalité pratique que pour la rationalité théorique, le "modèle apodictique » désigne chez Taylor un mode de raisonnement (a) opérant sur la base de "critères", soit de normes indéniables et extrinsèques aux agents, (b) arbitrant des "positions pleinement explicites» (fully explicit positions), et (c) produisant en première instance

14. Charles Taylor (I987), "Overcoming Epistemology», I995, p. 9.

15. Cf. Charles Taylor (I977), "Self-interpreting Animals», I98 5 a, p. 75.

16. Charles Taylor, "Merleau-Ponty and the Epistemological Picture", 2005, p. 42.

17. Cf. Charles Taylor, «Retrieving Realism ", 20I3, p. 64-67.

18. Cf. Frederick L.Will, I974, chapitre I. 
«des jugements absolus d'adéquation et d'inadéquation» (absolute judgments of adequacy/inadequacy $)^{19}$.

Notre auteur oppose à cette intelligence exclusivement apodictique de la raison un modèle "ad hominem " dont le propre est d'insister à la fois sur la possibilité d'expliciter notre situation herméneutique (ou nos arrièreplans) ainsi que sur l'ensemble des formes argumentatives qui dépendent de ce travail d'explicitation. Tout d'abord, bien loin de satisfaire à l'exigence de critères extrinsèques et indéniables, la connaissance de nos horizons implicites de compréhension consiste à interpréter/clarifier/formuler le "sens implicite» (inarticulate sense) que nous avons de notre situation et de nos finalités en tant qu'agents rationnels, de manière toujours révisable ou réinterprétable ${ }^{20}$. Cette prise intentionnelle sur le monde serait essentiellement «transitionnelle» (transitional grasp) dans la mesure où elle dépend de notre capacité de situer nos actions dans une perspective qui comporte toujours une intelligence du passé, du présent et du futur: de ce que nous sommes devenus, de nos possibilités actuelles et de ce que nous pouvons devenir - suivant les célèbres analyses phénoménologiques de la temporalité vécue chez Husserl et chez Heidegger ${ }^{21}$. Par ailleurs, en plus de cette "profondeur temporelle» (temporal depth), notre sens implicite de la réalité possède également une structure holistique, celui-ci mobilisant toujours une certaine "ontologie morale", une compréhension éthico-spirituelle globale de la condition humaine. C'est dire que notre éveil réflexif au "sens des choses» (the meaning of things) ${ }^{22}$, soit au monde tel qu'il se dévoile à la lumière de nos intentions et désirs, incorpore de manière inextricable des significations à la fois perceptives, pratiques, émotionnelles, relationnelles, éthiques, sociales, historiques et cosmiques. Ainsi, Taylor oppose notre "connaissance d'agent» (agent's knowledge), qui se traduit par une quête $\mathrm{du}$ «mot juste» en vue d'exprimer le sens de notre expérience vécue, à tout autre type de savoir que nous pourrions acquérir des objets qui nous entourent par le biais de l'observation ou d'une recherche empirique ${ }^{23}$. Nous retrouvons alors le concept heideggérien d'«interprétation explicitante» (Auslegung), central à l'herméneutique contemporaine et que notre auteur rend en anglais par «articulation».

Ensuite, l'approche ad hominem de Taylor fait ressortir, par-delà les limites étroites du modèle apodictique, la logique interne et l'importance des

19. Charles Taylor (I989), "Explanation and Practical Reason", I995, p. 40-I, 60.

20. "But something subject to amendment, which is nevertheless known without criteria, doesn't make sense on the foundationalist understanding" (Charles Taylor, "Retrieving Realism", 20I3, p. 78).

21. Cf. Charles Taylor, I989, p. 47; "Retrieving Realism», 2013, p. 77.

22. Charles Taylor, "Recovering the Sacred ", 20 I Ic, p. I I 4.

23. "The notion is that we are capable of grasping our own action in a way that we cannot come to know external objects or events " (Charles Taylor (I983), "Hegel's Philosophy of Mind", r985a, p. 80). 
transitions rationnelles rendues possibles par l'explicitation de notre prise implicite (temporelle/holistique) sur le monde. C’est dire que la pensée serait en mesure de progresser sur un mode "intrinsèquement comparatif » (inherently comparative), c'est-à-dire par le biais d'arguments consistant à relever les avantages relatifs d'une position $\mathrm{Y}$ sur une position $\mathrm{X}$ : "The claim is not that $Y$ is correct simpliciter but just that whatever is "ultimately true", $Y$ is better than $X^{24}$.» En ce sens, l'argumentation de type ad hominem (a) porterait sur des transitions plutôt que des critères; (b) reposerait sur la possibilité d'expliciter nos horizons de compréhension plutôt que d'arbitrer des positions entièrement explicites; et (c) demeurerait toujours faillible et ouverte à révision plutôt qu'elle ne produirait des jugements définitifs.

Il résulte de ces considérations une conception de la raison qui admet deux phases indivises, bien distinctes de la procédure de fondationreconstruction: une première de nature "clarificatrice» (an articulative face), qui serait affaire d'explicitation langagière et de "confiance anticipatrice " (anticipatory confidence), puis une seconde de nature plus argumentative qui s'efforcerait de mettre à l'épreuve ex post facto ces intuitions directrices en un va-et-vient permanent entre tâtonnement et ratification ${ }^{25}$. De la sorte, une forme de «foi épistémique » (epistemic faith) opérerait toujours en deçà des théories explicites et du travail méthodique des sciences expérimentales: "Reason cannot be simply reduced to explicit reasoning, the methodical rational operations which we carry out on our already articulated insights ${ }^{26}$.» Taylor mentionne en outre que cette critique autorise un certain retour à Platon, c'est-à-dire à l'idée d'un ordre de sens que l'intelligence humaine pressent, mais qui transcende inexorablement celui de nos discours: "His "logos", which we translate "reason", involves the articulation in words of insight, whose full nature can nevertheless not be fully communicated in words ${ }^{27}$.» De même, nous retrouvons ici la distinction centrale à l'ensemble de la tradition herméneutique entre le "verbe intérieur» et le «verbe extérieur », soit entre l'horizon intime et inépuisable du sens visé par la parole (le vouloir-dire) et le discours effectif, propositionnel et descriptif ${ }^{28}$.

24. Charles Taylor (I989), «Explanation and Practical Reason", I995, p. 54. Taylor discute ces arguments sous trois modalités: "Either they make better sense of inner difficulties than the interlocutor can (case 1); or they present a development which cannot be explained on the interlocutor's own terms (case 2); or they show the transition to Y to come about through a move that is intrinsically described as error-reducing (case 3)" (Ibid.).

25. Charles Taylor, "Reason, Faith and Meaning", 20I Ib, p. 9.

26. Ibid. Pour la notion de "foi épistémique", voir également Taylor, "Reason and its Adventures Since the Enlightenment », 2009, p. I 2.

27. Ibid. Voir également Charles Taylor (I982), "Rationality », I985b, p. I42-I 50.

28. Cette distinction d'origine stoïcienne (logos endiathetos/logos prophorikos) se trouve discutée et réhabilitée par Jean Grondin dans son important ouvrage sur l'histoire et les enjeux de la tradition herméneutique: L'universalité de l'herméneutique, I993. 


\section{Raison «médiationnelle» et raison «immergée»}

Le modèle apodictique est inséparable de ce que notre auteur dénomme la «théorie médiationnelle» (mediational theory) de la connaissance, par opposition à la «théorie du contact» (contact theory) qui allait de pair avec l'ontologie traditionnelle des formes intelligibles ${ }^{29}$. Alors que la théorie du contact discernait dans la connaissance un moment de l'être même, c'est-àdire une communion immédiate entre la pensée et la chose ${ }^{30}$, la théorie médiationnelle soutient qu'on ne peut accéder à la réalité «extérieure " «que par l'entremise " (only through) d'un médium « intérieur » comme les idées, la conscience, les impressions sensibles, les croyances, le langage, etc.: «We grasp the world through something, what is outside through something inner ${ }^{31}$.» Au concept médiéval de «repraesentatio » entendu comme participation aux formes intelligibles (par ressemblance, «similitudo») fut ainsi substituée l'idée d'une médiation de la réalité objective par l'élément connaissant, ou encore celle d'une constitution subjective de l'objectivité dans le contexte de l'idéalisme transcendantal. Toutefois, cette "structure d'intériorité/extériorité » (inner/outer structure) exercerait son influence bien au-delà des limites du représentationalisme classique et demeurerait patente en de nombreuses formulations du tournant linguistique de même que dans l'orthodoxie naturaliste actuelle: "This extraordinary continuity in modern thought reflects a very deep taken for granted topology of mindin-world, which in fact entraps even many of those who claim to have escaped it ${ }^{32}$."

Taylor relève deux principaux motifs à l'œuvre derrière ce tournant médiationnel. Le premier est d'ordre « ontologique» et concerne le statut de la perception et de la connaissance humaine en général dans le cadre nominaliste et mécaniste de la science moderne: "On the one hand, it is encouraged by a picture of the subject as one item in a disenchanted nature, understood by post-Galilean science ${ }^{33}$.» En un mot, la naturalisation de l'action et de la pensée humaines doit supposer un "point de transition" (transition point) par l'entremise duquel le monde physique peut agir sur la sensibilité (ou encore sur notre appareil neurocognitif), c'est-à-dire une frontière $\mathrm{d}^{\prime}$ "impressions passives" (passive impressions) où se joue la relation causale entre le corps-esprit et son environnement ${ }^{34}$. Le second motif est d'ordre «méthodologique» et concerne plutôt la manière dont la procédure

29. Charles Taylor, "Retrieving Realism», 20I3, p. 72.

30. "Here there is no hint of a mediating element, nothing separates us from reality. Real knowledge is a kind of unmediated contact" (Ibid.)

31. Charles Taylor, "Merleau-Ponty and the Epistemological Picture", 2005, p. 26.

32. Charles Taylor, «Reply", 2010, p. 697. Voir également: "Foundationalism and the Inner-Outer Distinction", 2002, p. I06-I IO; "Rorty and Philosophy", 2003, p. I62-I63; "Merleau-Ponty and the Epistemological Picture", 2005, p. 26-30.

33. Charles Taylor, "Merleau-Ponty and the Epistemological Picture», 2005, p. 4I.

34. Ibid. Cf. "Retrieving Realism», 2013 , p. 67. 
cartésienne de fondation-reconstruction exige l'invention d'un «étrange événement limite" (strange boundary event), soit d'un niveau de connaissance antérieur en droit à toute interprétation ou toute activité cognitive de la part du sujet connaissant ${ }^{35}$. En outre, notre auteur insiste avant tout sur la complémentarité de ces deux motifs, puisque tous deux génèrent et consolident la même structure médiationnelle: "The given prior to interpretation, and the passively received come together as two sides of the same entity, two ways of describing its basic nature. [...] This is the basis of what was later called the Myth of the (purely) Given, and of all the confusions between the "space of causes" and the "space of reasons" which this involved ${ }^{36}$."

À l'encontre de ces développements, Taylor fait valoir que l'explicitation des contextes d'intelligibilité (ou des arrière-plans) de l'expérience vécue au sein de la philosophie post-kantienne - notamment chez Heidegger, Merleau-Ponty et Wittgenstein - marqua la naissance de nouvelles théories du contact ou de l' «immersion» (immersion theories): "The contact here is not achieved on the level of Ideas, but is rather something primordial, something we never escape. It is the contact of living, active beings, whose life forms involves acting in and on a world which also acts on them ${ }^{37}$." Ces méditations "méta-critiques» sur les horizons implicites de la conscience intentionnelle permettent selon notre auteur de récuser à la fois la naturalisation de la connaissance et l'idéal fondationnaliste qui assurent secrètement la pérennité de la théorie médiationnelle. En effet, Taylor soutient que toute objectivation théorétique de même que toute réflexion critique présupposent de manière indispensable notre affairement incarné et pratique dans le monde, soit l' 'In-der-Weltsein" (Heidegger) ou "être-au-monde" (Merleau-Ponty): "The very idea of an inner zone with an external boundary can't get started here, because our living things in a certain relevance can't be situated "within" the agent; it is in the interaction itself ${ }^{38}$.»

Taylor admet volontiers que le dualisme épistémologique paraît plausible lorsque l'on considère notre rapport au monde au regard de nos croyances explicites: "My beliefs about the moon can be held, even actualized in my present thinking, even if the moon is not now visible; perhaps even though it does not exist, if it turns out to be a fiction ${ }^{39}$." Toutefois, notre engagement perceptif-pratique dans un environnement donné implique

35. "On the one hand, it has to be about the world, present a unit of information, be a small item of knowledge, and hence belong to the space of reasons. On the other, it has to be prior to all interpretation, its having the content it has must be a brute fact, not in any way the result of thought or reasoning activity on our part" (Charles Taylor, "Merleau-Ponty and the Epistemological Picture", 2005, p. 42.

36. Charles Taylor, «Retrieving Realism», 20I3, p. 67.

37. Ibid., p. 73 .

38. Charles Taylor, «Merleau-Ponty and the Epistemological Picture», 2005, p. 39.

39. Ibid., p. 33 . 
quant à lui "des capacités de plusieurs ordres" (a spectrum of rather different abilities) dont l'exercice présuppose à son tour cet environnement, de sorte que notre prise sur les choses ne peut aucunement être séparée de ces dernières ${ }^{40}$. Cela signifie que notre "contact avec la réalité » n'est pas une thèse dont on pourrait véritablement douter, mais bien l'arrière-plan sur lequel se détachent toute perception et toute pensée: "The reality of contact with the real world is the inescapable fact of human (or animal) life and can only be imagined away by erroneous philosophical arguments ${ }^{41}$."

\section{Raison «désengagée» et raison «située»}

Selon Taylor, la raison apodictique-médiationnelle peut également être dite "désengagée " (disengaged reason) pour des motifs semblables à ceux qui présidèrent au tournant médiationnel. Premièrement, l'objectivation du monde dans le cadre mécaniste de la science classique fut accompagnée d'une certaine "neutralisation du cosmos " en vertu de laquelle ce dernier en vint à perdre sa dimension normative traditionnelle: "[...] the cosmos is no longer seen as the embodiment of meaningful order which can define the good for us. And this move is brought about by our coming to grasp this world as mecanism ${ }^{42}$ ». Il en découle que le monde ne pouvait désormais plus "nous aider à devenir des hommes ${ }^{43}$ ", pour reprendre la splendide formule de Rémi Brague, mais prêtait plutôt le flanc à l'adoption d'une posture instrumentale et reconstructive. En outre, l'auto-objectivation du sujet connaissant doit en toute rigueur générer une image de soi en tant que conscience pure et détachée, c'est-à-dire capable en principe d'une forme de désengagement méthodique total. De fait, ce «moi ponctuel» (punctual self) est le corrélat nécessaire de l'ontologie objectiviste qui estime que la science doit s'affranchir de sa gangue subjective afin de se représenter adéquatement la réalité elle-même: "Radical objectivity is only intelligible and accessible through radical subjectivity ${ }^{44}$."

De manière concomitante, la procédure cartésienne de fondationreconstruction exhorte à un même dés-engagement de notre expérience vécue et incarnée (embodied experience), une même "ontologisation de la

40. "The locus here is the ability to move-in-this-environment. It exists not just in my body, but in my body-walking-the-streets » (Idem).

41. Ibid., p. 40.

42. Charles Taylor, I989, p. I48-I49, I60-I64.

43. Rémi Brague, I999, p. 3 I 6.

44. Ibid., p. I75-I 76. Taylor insiste en plusieurs endroits sur l'idée que l'ontologie naturaliste moderne repose sur la distinction - centrale à l'âge classique - entre les propriétés premières, "absolues» ou intrinsèques à la réalité, et les propriétés secondes, «relatives» ou dépendantes de la constitution du sujet. Cf. Charles Taylor, "Introduction", I985a, p. 2-3; (I99I) "Lichtung or Lebensform: Parallels between Heidegger and Wittgenstein", I995, p. 65 . 
perspective désengagée " (ontologizing of the disengaged perspective $)^{45}$. En effet, le doute radical selon lequel la perception est toujours sujette à la possibilité d'une illusion généralisée doit assurer le détachement d'une sphère d'évidences premières - nos idées claires et distinctes, les impressions sensibles - dont la validité serait parfaitement indépendante de l'existence effective de la chose éprouvée et pensée ${ }^{46}$. Toutefois, il importe de le mentionner, Taylor estime que toute "compréhension théorétique " (theoretical understanding) vise en fait à réaliser une perspective désengagée sur la réalité ${ }^{47}$ et que l'idéal de désengagement méthodique au cœur des sciences expérimentales est en lui-même louable et irrévocable. Le problème surgit plutôt quand l'épistémologie en vient à dicter l'ontologie, c'est-à-dire au moment où les procédures rationnelles se trouvent "réifiées » ou "projetées dans la constitution même de l'esprit» (read into the very constitution of the mind $)^{48}$. Une telle réification "rationaliste» peut prendre une forme dualiste, lorsque la res cogitans se voit épurée de toute distorsion sensible ou imaginaire, ou encore naturaliste, lorsque l'on présume que les impressions sensibles (indubitables et atomiques) coïncident avec les conditions causales effectives de la connaissance sous la forme de stimulations chimiques/mécaniques ${ }^{49}$.

À l'encontre de ces ontologies du désengagement, notre auteur propose de déconstruire l'objectivisme et le projet fondationnaliste en leur opposant la notion de "liberté située " (situated freedom) ${ }^{50}$ ou encore d'un "agir engagé" (engaged agency): "[...] it is an agency whose experience is only made intelligible by being placed in the context of the kind of agency it $i s^{51}$ ». En ce sens, la distinction entre les «conditions causales» de l'expérience et l'ensemble des "conditions d'intelligibilité » ou des arrière-plans qui façonnent notre monde vécu s'avère ici cruciale. Alors que les premières seraient de nature objective, atomique, neutre et explicite ${ }^{52}$, l'explicitation des conditions d'intelligibilité (i) puiserait au contraire dans la connaissance tacite que nous possédons de notre situation et de nos fins en tant qu'agents

45. Charles Taylor (I99I), «Lichtung or Lebensform: Parallels between Heidegger and Wittgenstein ", I995, p. 66.

46. "Instead of remaining in the incurable uncertainty that rehearsing the sources of error was meant to bring on, the solvent of doubt is made to hit one irreducible kernel, namely, our experience of the world. " (Charles Taylor, "Foundationalism and the Inner-Outer Distinction", 2002, p. 108).

47. Charles Taylor (I982), «Rationality», I985b, p. I36.

48. Charles Taylor (I99I), "Lichtung or Lebensform: Parallels between Heidegger and Wittgenstein ", I995, p. 6I.

49. Charles Taylor, "Foundationalism and the inner-outer distinction", 2002, p. I09I Iо. Cf. «Merleau-Ponty and the Epistemological Picture », 2005, p. 43.

50. Charles Taylor, I977, p. 563; 1989, p. 5 I 5.

51. Charles Taylor (I99I), «Lichtung or Lebensform: Parallels between Heidegger and Wittgenstein ", I995, p. 66.

52. Ibid., p. 62-66. 
rationnels, c'est-à-dire dans notre "connaissance d'agent "; (ii) comporterait une "tendance holistique intrinsèque" (an inherently bolistic bent $)^{53}$; (iii) renverrait toujours au "sens expérientiel»(experiential meaning) ${ }^{54}$ que revêt le monde pour un agent défini à partir de ses besoins, capacités, désirs, aspirations, etc.; et (iv) mettrait en relief une situation herméneutique largement implicite, ou encore une «compréhension incarnée " (embodied understanding), que la réification naturaliste de la pensée occulterait entièrement ${ }^{55}$.

Face à l'ambition fondationnaliste, la notion même d'arrière-plan se trouve mise en valeur contre l'idéal de désengagement total. En effet, Taylor soutient que l'idée d'une «intuition apodictique » dissimule nécessairement le phénomène des conditions d'intelligibilité, sous les traits d'un véritable paradoxe: les intuitions premières et atomiques requises par la procédure cartésienne, qu'elles soient rationnelles ou sensibles, se présentent comme étant à la fois intelligibles et indépendantes de tout contexte d'intelligibilité $^{56}$. Or, au contraire, toute compréhension possède ses horizons implicites de "pré-compréhension" (preunderstanding), et le phénomène est tel que le projet d'une explicitation totale de ces derniers s'avère essentiellement incohérent, tout acte d'explicitation possédant à son tour ses propres conditions de possibilité/intelligibilité: "Disclosure is invariably accompanied by hiddenness; the explicit depends on the horizon of the implicit ${ }^{57}$." Animal qui s'auto-interprète, l'humain est ainsi un être qui vit toujours-déjà au sein d'une compréhension préalable de son être:

Human thinking is situated thinking, in which any questions that can be raised only makes sense against a background or framework of the taken uterly for granted. Our capacity for rational reflexion is such that some of what was formerly background can now be put into question, but only against its own background of the unchallenged. To grasp someone's form of life is to understand this pattern of questions against the unnoticed background, perhaps by participating in it unreflectively, perhaps also by some very partial explicit understanding of its limitations. ${ }^{58}$

53. Ibid., p. 72. "A certain holism gets in the way. [...] It undercuts completely the atomism of the input. First, because the nature of any given element is determined by its "meaning" (Sinn, sens), which can only be defined by placing it in a larger whole. And even worse, because the larger whole is not just an aggregation of such elements. " (Charles Taylor, "What's Wrong with Foundationalism?: Knowledge, Agency, and World», 2000, p. I I6.

54. Charles Taylor (I97I), "Interpretation and the Sciences of Man", I98 5 b, p. 22-23.

55. Charles Taylor (I992), "To Follow a Rule", I995, p. I70-I77.

56. Charles Taylor (I99I), "Lichtung or Lebensform: Parallels between Heidegger and Wittgenstein ", I995, p. 72.

57. Charles Taylor (1983), "Hegel's Philosophy of Mind», I985a, p. 96. Cf. (I99I), «Lichtung or Lebensform: Parallels between Heidegger and Wittgenstein", I995b, p. 69-70.

58. Charles Taylor, «Ethics and Ontology», 2003, p. 3 I3. 


\section{Raison «désignative» et raison «expressive»}

Sur le plan de la philosophie du langage, Taylor souligne à bon droit que la raison épistémologique doit être située dans le contexte du nominalisme moderne, qui détermine à la fois (i) l'importance que revêt la question du langage à notre époque ainsi que (ii) la prédominance des «théories désignatives" (designative theories) de la signification. En ce sens, les "cosmologies sémiologiques" (semiological cosmologies) qui dominaient le Moyen Âge ne pouvaient reconnaître au langage humain que le rôle d'un "vêtement extérieur ", puisque le privilège revenait à la pensée de pouvoir prendre part directement au Verbe divin ${ }^{59}$. La révolution nominaliste consista d'abord à rejeter ces théories du "logos ontique» au nom de la souveraineté radicale de Dieu, jugée incompatible avec l'idée d'un ordre d'essences immuables, puis au nom de la souveraineté (ou de l'autonomie) de la raison humaine, suivant l'esprit général de la Renaissance. Il devint dès lors inévitable de concevoir le langage comme l'étoffe même de la pensée, le véhicule indispensable des "idées": "It was the rebellion against this semiological view of the universe, in nominalism, which began to make language important. [...] It is the new home of the universal, which has been chased out of the real ${ }^{60}$."

Cette promotion nouvelle du langage fut indissociable d'une conception purement «désignative» voulant que la signification ne soit plus une dimension intrinsèque de la réalité, mais bien une propriété que possèdent les mots (ou "noms", nomina) dans la mesure où ceux-ci permettent de référer au monde: "Words mean because they designate something ${ }^{61}$." Cette approche désignative devint bientôt une composante essentielle de la tradition épistémologique, notamment chez Hobbes, Locke et Condillac, faisant du langage un instrument malléable par le biais duquel la raison désengagée peut exercer un empire sur ses propres représentations, c'est-àdire construire une image intérieure adéquate de la réalité objective ${ }^{62}$. De la sorte, le langage fonctionnerait dans un «cadre » anthropologique (cognitif et comportemental) pouvant lui-même être compris indépendamment $d u$ langage, toute signification étant enchâssée ou "encadrée » (enframed) au sein de l'univers objectif comme son versant factice et «intérieur » ${ }^{63}$.

59. "So langage plays a small and marginal role in the theories of the ancients " (Charles Taylor (I980), «Language and Human Nature», I985a, p. 222).

60. Ibid., p. 224.

61. Idem.

62. "It is an instrument of control in gaining knowledge of the world as objective process» (Ibid., p. 228).

63. "The instrumental view is an "enframing" theory. I shall use this term to describe attempts to understand language within the framework of a picture of human life, behavior, purposes, or mental functioning, which is itself described and defined without reference to language» (Charles Taylor (I99I), "Lichtung or Lebensform: Parallels between Heidegger and Wittgenstein ", I995, p. I0I). 
En réaction contre cette approche désignative-instrumentale, le Romantisme vit naître un ensemble de "théories expressives-constitutives " (expressive-constitutive theories), en particulier chez Herder, Hamann et Humboldt, dont le propre était d'insister sur l'inséparabilité de la pensée et $d u$ langage dans le phénomène énigmatique de l'«expression ». Ce dernier renvoie au fait que certaines significations - l'inquiétude ou la joie que révèle notre visage, par exemple - ne viennent à l'existence que par leur manifestation concrète dans nos vies; elles n'ont de réalité que par leur incarnation dans nos discours et nos actes. L'expression est irréductible à toute objectivation/fondation qui aurait pour effet de détacher la chose du signe, la signification de son médium expressif: "What expression manifests can only be manifested in expression, so that expressive meaning cannot be accounted for independently of expression ${ }^{64}$. " En ce sens, l'intuition fondamentale des penseurs expressivistes est que le langage, ressaisi depuis l'expérience vivante de la "parole» (speech), possède la même logique essentielle: il manifeste et réalise un certain "éveil réflexif » (reflective awareness) qui ne s'avère compréhensible qu'à partir de lui-même, de ses normes intrinsèques $^{65}$. La parole ouvrirait ainsi une "dimension sémantique" (semantic dimension) se caractérisant par notre "sensibilité à des enjeux irréductibles de justesse " ( sensitivity to irreducible issues of rightness "), c'est-à-dire par notre accès à un ordre de significations ne pouvant être connues que par le biais de l'expression ${ }^{66}$.

Alors que l'approche désignative-instrumentale tend à démystifier le langage en tirant au clair les corrélations objectives entre les signes, nos comportements et le monde, l'approche expressive-constitutive fait plutôt ressortir son "mystère" essentiel ${ }^{67}$. D'une part, elle place au cœur de ses considérations les propriétés «anthropocentriques» que s'efforce d'expulser la raison épistémologique, puisque les significations expressives sont inséparables de leur expression et que l'expression est elle-même inséparable de l'existence d'un agent incarné et situé68. Parmi ces significations figurent, par-delà nos activités « désignatives » ou descriptives, un «horizon de préoccupations» (borizon of concerns) proprement humaines et inaliénables, c'est-à-dire certains sentiments moraux (admiration, honte, culpabilité, etc.), certaines relations interpersonnelles (amour, amitié, etc.) et, surtout, ce que Taylor dénomme nos "évaluations fortes" (strong evaluations) touchant la vie bonne et signifiante, auxquelles nous reviendrons sous peu.

64. Charles Taylor (I980), "Language and Human Nature», I985a, p. 2 I9.

65. "What is crucial to language is what is realized in speech, the expression/realization of reflection."; "The expressive dimension is fundamental to language, because it is only in expression that language comes to be" (Ibid., p. 229).

66. Charles Taylor (I99I), "The Importance of Herder», I995, p. 84.

67. Charles Taylor (1980), "Language and Human Nature», I985a, p. 2 I9.

68. "Now an expressive account of meaning cannot avoid subject-related properties" (Ibid., p. 22I). 
D'autre part, l'approche expressiviste met en relief les «structures profondes» (depth structures) du langage à la lumière desquelles la parole se présente comme la pointe d'un iceberg en mouvement, mobilisant à chaque instant des horizons de sens inépuisables et indomptables ${ }^{69}$. À cet égard, le concept d'expression aménage un espace théorique afin accueillir la pluralité des médiums expressifs, incluant notamment, par-delà la "parole en mots" (speech in words), les formes "projectives » d'expression telles que les gestes, les styles, les postures, etc., ainsi que les formes «symboliques » au cœur de l'art et de la vie religieuse ${ }^{70}$.

En plus de ces percées déterminantes, le tournant expressiviste a également l'insigne mérite d'avoir soulevé un ensemble de questions essentielles touchant les pouvoirs expressifs de l'être humain. Parmi ces questions, deux méritent une attention particulière: Qui est le sujet de l'expression? Quel est le statut des significations expressives qui façonnent nos vies?

$\mathrm{Au}$ regard de la première question, Taylor estime que l'approche désignative-instrumentale occulte nécessairement le caractère "dialogique " de l'expression, qui naît et s'insère toujours au sein d'une communauté linguistique. En effet, celle-ci doit concevoir la communication entre les agents en termes strictement "monologiques", soit en tant qu'échange de "représentations" ou d'états mentaux individuels, puisque toute connaissance trouve sa genèse "dans» l'esprit ou l'appareil cognitif du sujet ${ }^{71}$. Or l'élément fondamental de la parole est plutôt celui de la "conversation » où les interlocuteurs partagent un espace commun d'intelligibilité, un «espace public ( public space): "To express something, to formulate it, can be not only to get it in articulate focus, but also to place it in public space, and thus bring us together qua participants in a common act of focussing ${ }^{72}$." Plus encore, notre auteur affirme que l' «entente» dialogique, suivant le mot de Gadamer (Verständigung), constitue une condition «transcendantale» tant pour l'acquisition que pour l'exercice de la compétence linguistique: «[...] the very confidence that we know what we mean, and hence our having our own original language, depends on this relating. The original and (ontogenetically) inescapable context of such relating is the face-to-face one in which we actually agree ${ }^{73}$ ".

En ce qui concerne le statut des significations expressives, il est évident que le tournant expressiviste est bien loin d'avoir mis fin au subjectivisme moderne, ayant au contraire inspiré certaines de ses formes les plus «viru-

69. "Our language is always more than we can encompass; it is in a sense inexhaustible» (Ibid., p. 23I).

70. Charles Taylor (I992), "Heidegger, Language, and Ecology", I995, p. I IO-III.

71. "It deems all states of knowledge and belief to be states of individual knowers and believers. Communication is then the transmittal, or attempted transmittal, of such states" (Charles Taylor (I980), "Theories of meaning", I985a, p. 259).

72. Idem.

73. Charles Taylor, I989, p. 38. 
lentes $»^{74}$. Taylor propose pour sa part une interprétation résolument «antisubjectiviste » de la «dimension sémantique » et de l'horizon de préoccupations proprement humaines qui se manifeste en elle: les significations expressives dépendent de nous en tant qu'agents linguistiques ou "animaux qui s'autointerprètent ", elles se présentent comme un ordre nécessairement "médiat », sans perdre leur indépendance ou leur caractère de transcendance par rapport à notre effort d'expression/compréhension. En ce sens, l'expression ne relèverait ni d'une simple découverte ni d'une pure création, mais participerait concurremment des deux: "Expression partakes both finding and making ${ }^{75}$." L'expressivisme herméneutique de Taylor rejoint ainsi l'adage de Gadamer "l'être qui peut être compris est langage» (Sein, das verstanden werden kann, ist Sprache $)^{76}$, qui signifie non seulement que la pensée possède toujours un caractère langagier, mais aussi et surtout que notre intelligence demeure fondamentalement dirigée sur "la langue des choses» (die Sprache der Dinge), c'est-à-dire sur le sens ou l'intelligibilité intrinsèque de la réalité humaine et historique ${ }^{77}$.

\section{Raison «dépassionnée» et raison «passionnée»}

S'il est bien connu que la philosophie morale de notre auteur occupe une place prépondérante dans son œuvre, il conviendra d'aborder cette dernière dans la perspective particulière de sa critique de l'épistémologie moderne. En un mot: 1 '«image épistémologique» aurait contribué à occulter le lien crucial entre la raison et les "passions": "[...] let this term stand here for our perception of life meanings through feeling - through the way that these meanings move $u s^{78}$ ". À cet effet, Taylor rappelle que la vision rationnelle du cosmos comportait généralement dans la tradition éthique des anciens une intelligence du Souverain Bien qui était elle-même indissociable d'un sentiment d'admiration et d'amour ${ }^{79}$. De plus, dès Aristote, cette vision du Bien relevait moins d'une science rigoureuse que d'une capacité de discernement pratique (phrōnesis) s'exerçant sur l'arrière-plan d'un ensemble complexe de dispositions (hexeis).

À l'encontre de cette conception, le modèle apodictique de la raison et l'ontologie objectiviste concoururent à réduire notre existence éthique et

74. Charles Taylor (I992), «Heidegger, Language, and Ecology», I995, p. I I 7.

75. Idem.

76. Hans-Georg Gadamer (I960), trad. I996, p. 500.

77. Hans-Georg Gadamer (I960), "La nature de la 'res'et le langage des choses », I99I. À ce sujet, voir notamment l'article lumineux de Jean Grondin intitulé «La thèse de l'herméneutique sur l'être", 2006.

78. Charles Taylor, «Reason, Faith and Meaning», 20I rb, p. I3. Le terme était utilisé en un sens analogue par Michael Polanyi lorsque celui-ci discutait de la "dimension tacite» de la connaissance humaine: Personal Knowledge. Towards a Post-Critical Philosophy, 1958, chap. Iо.

79. Charles Taylor, «Reason, Faith and Meaning », 20 I Ib, p. I4. 
spirituelle à l'"enclos de la moralité » (corral of morality) ou de l'action obligatoire $^{80}$. Cette réduction "rationaliste» impliqua à la fois le renversement de la philosophia practica aristotélicienne à la faveur d'une procédure à critère unique - comme ceux de la maximisation de l'utilité ou du principe d'universalisation - ainsi que le rétrécissement de l'éthique à la seule question de savoir ce que nous devrions faire (what we ought to do), au détriment de toute réflexion sur la vie bonne (what it is good to be) et sur ce qui mérite notre allégeance et notre amour (what it is good to love). En outre, les "passions» qui nous reliaient autrefois à l'ordre moral furent jugées proprement inadmissibles puisque notre perception rationnelle de la réalité «objective» serait par nature foncièrement indépendante de nos réactions émotionnelles: "Passion can disturb us, if it is too strong, or too subtly seductive of our reasoning powers, but it cannot help ${ }^{81}$. " Il en résulte que la raison épistémologique s'avère également une raison "dépassionnée » (dispassionate reason).

Taylor rejoint à plusieurs égards les diverses critiques «néonietzschéennes » et "néo-aristotéliciennes » visant aujourd'hui à élargir la réflexion en philosophie morale au-delà de l'«enclos» de l'action obligatoire, vers le «champ» ouvert de l'éthique et, dans quelques cas, vers la "forêt» déconcertante de la vie spirituelle et religieuse ${ }^{82}$. Le cœur de sa position, toutefois, concerne le caractère inéluctable (ou "transcendantal») des "évaluations fortes": nos réactions et jugements moraux présupposeraient à titre de contexte d'intelligibilité un horizon pluriel d'intuitions touchant le type d'existence que nous aspirons à mener, ce qui vaut d'être désiré et aimé $^{83}$. Contrairement à nos "évaluations faibles» (weak evaluations), qui dépendent de nos choix et de nos préférences temporaires, les évaluations fortes ne sont pas choisies mais bien "constatées", de sorte qu'on ne saurait les nier ou s'en détourner sans éprouver ce comportement comme une forme de confusion ou de dérive morale ${ }^{84}$. Ainsi, ces dernières coïncideraient avec notre compréhension largement implicite de la vie bonne, le plus souvent structurée par un langage de vertus et de vices, et exprimeraient ce que notre auteur décrit comme nos «biens de vie» $\left(\right.$ life goods) ${ }^{85}$.

L'enjeu crucial demeure ici la tension entre cette caractérisation phénoménologique de notre vie éthique et l'ontologie objectiviste dominante qui commande pour sa part l'adoption d'un certain «antiréalisme métaé-

80. Charles Taylor (I996), "Iris Murdoch and Moral Philosophy», 20 I ra, p. 5.

81. Charles Taylor, "Reason, Faith and Meaning", 20 I Ib, p. I4.

82. Charles Taylor (1996), "Iris Murdoch and Moral Philosophy ", 20 I ra, p. 5.

83. "[...] the claim is that living within such strongly qualified horizon is constitutive of human agency, that stepping outside these limits would be tantamount to stepping outside what we would recognize as integral, that is, undamaged human personhood" (Charles Taylor, I989, p. 27).

84. Charles Taylor, (I977), "What is Human Agency?", I985a, p. 33.

85. Charles Taylor, I989, p. 93. 
thique». Une telle position soutient que nos évaluations morales ne constituent que des projections subjectives sur une réalité en elle-même dépourvue de toute signification humaine: "A neutral world is given practical shape by the "values" that human agents project onto $i t^{86}$." De fait, tous les jugements moraux doivent posséder dans la perspective objectiviste un statut «étrange" (queer) dans la mesure où ils portent sur des propriétés (courageux/peureux, noble/vil, etc.) qui n'auraient aucune existence sans la nôtre et ne peuvent être décrites/explicitées qu'en termes "anthropocentriques». Or, s'il est vrai que toute propriété morale est inséparable de notre existence incarnée et située, ne se manifestant qu'à «l'interface du Dasein et du monde" (in interface between Dasein and world), les évaluations fortes, soutient Taylor, se présentent néanmoins comme un ordre d' "exigences" (demands) ou de significations "transcendantes", indépendantes de nos choix ou de notre volonté: "It re-establishes the non-arbitrary, nonprojective character of certain demands on us, which are firmly anchored in our being-in-the-world. These demands do not just emanate from us, but at the same time, they are not inscribed in the universe (or the Universe and God) independently of us. They arise in our world ${ }^{87}$."

Éthique et ontologie s'avéreraient ainsi, en raison du caractère inéluctable des évaluations fortes, inextricablement liées. Même la raison épistémologique, comme nous le mentionnions lors de nos commentaires introductifs, se révélerait en fait motivée — voire «surdéterminée » (overdetermined) - par un ensemble d'idéaux moraux qui en assurent jusqu'à aujourd'hui la pérennité. Cela dit, notre unique mode d'accès à cet "ordre moral» (moral order) serait le «sentiment» (feeling), la prescience affective de ce qui revêt pour nous une importance décisive: "This is a domain to which there is no dispassionate access ${ }^{88}$. " En ce sens, nos sentiments moraux devraient être considérés comme des "perceptions rationnelles ${ }^{89}$ incorporant une compréhension implicite de notre situation et de ce qui rend nos biens de vie dignes de notre amour, dévotion, allégeance, admiration, respect, etc., soit une intelligence de ce que Taylor dénomme les «biens constitutifs » (constitutive goods $)^{90}$. En outre, ces biens constitutifs se présenteraient à leur tour, en tant que «sources morales» (moral sources), comme ce qui nous inspire, nous motive, nous guide ou encore comme ce qui nous donne

86. Charles Taylor, «Reason, Faith and Meaning», 20I Ib, p. I8.

87. Charles Taylor, "Recovering the Sacred", 20 I Ic, p. II 7.

88. Charles Taylor (I977), "Self-interpreting animals", I98 5 a, p. 62.

89. Cf. Charles Taylor, "Reason, Faith and Meaning", 201 Ib, p. I3-18.

90. "By that I mean features of ourselves, or the world, or God, such that their being what they are is essential to the life goods being good. Examples in well-known traditional views are: God having created us and calling us is a constitutive good for Judaeo-ChristianIslamic theism; the idea of the Good is one such for Plato; for Aristotle, our being animal having logos is one» (Charles Taylor (I996), "Iris Murdoch and Moral Philosophy », 20I Ia, p. Iо). 
le "pouvoir de faire le bien et d'être bons» (which empowers us to do and be good $)^{91}$. Comme nous le soulignions plus tôt, notre sens implicite et holistique du monde engage toujours une compréhension de la condition humaine, de nos possibilités (d'action et de transformation) ainsi que de nos finalités dernières.

Loin d'être réductibles à des sensations brutes et non épistémiques telles que la nausée ou la douleur, explicables en termes neurophysiologiques, les «passions» humaines peuvent être explorées sous la forme d'une "réflexion profonde»(deep reflection) sur les enjeux fondamentaux de notre vie ${ }^{92}$. Un tel effort herméneutique serait en mesure de clarifier nos sentiments et d'améliorer notre "contact» avec les sources morales de notre existence, de "réinsuffler un peu d'air dans les poumons à demi affaissés de l'esprit " (bring the air back into the half-collapsed lungs of the spirit $)^{93}$. De fait, ce processus de ressourcement moral et d' «individuation expressive» (expressive individuation), bien que généralement dissimulé par la conscience naturaliste moderne, coïnciderait avec l'ultime mystère de la nature humaine, c'est-à-dire de cet «animal qui possède le logos» (animal possessing logos, zoon logon echon): "In fact, the mystery resides in our having certain ends of life, which we endlessly redefine, without their even becoming totally transparent, that is, without our ever fully understanding the reasons for them ${ }^{94}$.»

Cela dit, notre accès à l'ordre moral ne saurait être «immédiat» à la manière des significations pré-linguistiques qui nous sollicitent au niveau de notre expérience perceptive et pratique du monde. Au contraire, ces significations expressives ne peuvent être saisies que par le biais d'une formulation particulière; elles sont inséparables des médiums expressifs (corporels, conceptuels ou symboliques) créés pour les manifester. Plus encore, ce contact expressif ne se réalise que dans un «récit» ou une «mise en intrigue » de notre vie, suivant la structure «transitionnelle» (temporelle/historique) qui caractérise toute action située: les passions s'avèrent essentiellement narratives, et seule une forme de généalogie est en mesure de faire ressortir toute la richesse et la complexité de l'ontologie morale qui enveloppe implicitement notre existence: "[...] genealogy goes to the heart of the logic of practical reasoning ${ }^{95} "$. Autrement dit, seule une lecture diachronique de notre situation herméneutique permet d'esquisser une «topographie morale» au sein de laquelle deviennent intelligibles les préoccupations qui nous animent et, plus spécialement, permet de prendre le pouls des conflits et dilemmes constitutifs de l'identité moderne.

91. Charles Taylor, I989, p. 93.

92. Charles Taylor (I977), "What is Human Agency?", I98 5 a, p. 42.

93. Charles Taylor, I989, p. 520.

94. Charles Taylor (2008), "Language Not Mysterious?» (20I Ia), p. 55.

95. Charles Taylor, I989, p. 73. 


\section{Raison «procédurale» et raison «substantielle»}

En dernier lieu, la conception apodictique, médiationnelle, désengagée, désignative et dépassionnée de la raison marque aussi une rupture avec la conception «substantielle» (substantive reason) qui régnait dans la tradition antico-médiévale, selon laquelle «être rationnel» signifiait saisir adéquatement l'ordre rationnel du monde (kósmos) : "I call a notion of reason substantive where we judge the rationality of agents or their thoughts and feelings in substantive terms. This means that the criterion for rationality is that one get it right ${ }^{96}$.» Du moment où la réalité ne pouvait plus être conçue comme l'auto-manifestation ou l'incarnation d'une Raison préexistante (un «logos ontique»), il devint quasi-inévitable de comprendre la rationalité humaine de façon "procédurale» (procedural reason), c'est-à-dire comme la faculté de penser et de vivre conformément à un canon ou un ensemble de normes déterminées - par exemple: la procédure cartésienne de fondationreconstruction, la méthode expérimentale, l'impératif catégorique de Kant, le "voile d'ignorance» chez John Rawls, l'éthique de la discussion chez Jürgen Habermas, notre «logiciel» neurocognitif, etc. ${ }^{97}$. Tout particulièrement, la connaissance ne consisterait plus à «découvrir» (find) un ordre de sens qui précède et fonde notre effort de compréhension, mais bien à "(re) construire» (construct, build) l'ordre de nos représentations suivant une méthode capable de garantir l'adéquation de la pensée et du monde: «Rationality is now an internal property of subjective thinking, rather than consisting in its vision of reality ${ }^{98}$."

La conception "ad hominem ", "immergée », "située ", « expressive " et "passionnée» de la raison défendue par Taylor culmine pour sa part en un certain "réalisme non problématique» (unproblematical realism) ${ }^{99}$. Notre compréhension de la réalité peut alors être distinguée de la réalité ellemême, qui transcende par essence toute perspective finie, sans que puisse être mise en doute de manière cohérente notre prise sur le réel. Ce réalisme possède ainsi deux composantes essentielles. La première est l'idée que notre immersion perceptive-pratique dans le monde est plus fondamentale que tout doute et toute croyance, de sorte que nous ne pouvons jamais être totalement dans l'erreur ou l'illusion: "Our formulations of reality may involve

96. Ibid., p. 85 .

97. "We could say that rationality is no longer defined substantively, in terms of the order of being, but rather procedurally, in terms of the standards by which we construct orders in science and life" (Ibid., p. I 56). "Reason is not that faculty in us which connects us to an order of things in the universe which itself can be called rational. Rather reason is that faculty whereby we think properly." (Charles Taylor (I99I), "Lichtung or Lebensform: Parallels between Heidegger and Wittgenstein ", I995, p. 64).

98. Charles Taylor, I989, p. I 56. "As the notion of 'idea'migrates from its ontic sense to apply henceforth to intra-psychic contents, to things "in the mind", so the order of ideas ceases to be something we find and becomes something we build" (Ibid., p. I44).

99. Charles Taylor, «Merleau-Ponty and the Epistemological Picture», 2005, p. 39. 
blind spots and distorsions. We may, for instance, be badly misrepresenting the life of another people. But these formulations do not exhaust our grip on reality ${ }^{100}$. " La seconde composante est la distinction entre «schèmes " et "contenus », ou encore entre nos interprétations et l'être des choses: si toute expérience humaine n'est intelligible qu'au sein d'une situation herméneutique déterminée, le phénomène primordial demeure la capacité d'ajustement de la pensée à la réalité, c'est-à-dire la révision constante de nos schèmes conceptuels et symboliques en direction de la vérité ${ }^{101}$. Dans ces conditions, la rationalité humaine peut être de nouveau conçue de manière substantielle comme la capacité de comprendre le sens des «choses ellesmêmes» (die Sachen selbst).

De manière complémentaire, Taylor évoque ce qu'il dénomme le "principe de la meilleure interprétation»(best-account principle): est aussi réel que possible ce dont on ne saurait faire l'économie dans notre meilleure interprétation des choses ${ }^{102}$. Aucune considération épistémologique ne devrait prévaloir sur ce principe, qui concerne aussi bien notre "connaissance d'agent», c'est-à-dire l'ensemble des significations prélinguistiques et expressives qui façonnent notre expérience du monde, que notre connaissance d'objet ou d'événements extérieurs. La réalité est ce qui résiste à nos préjugés, à notre effort de compréhension, qu'il s'agisse du monde objectif que découvrent les sciences expérimentales ou encore du monde vécu tel qu'il se dévoile à un agent en situation: "What is real is what you have to deal with, what won't go away just because it doesn't fit with your prejudices ${ }^{103}$."

Il paraît toutefois évident que les significations qui façonnent notre monde vécu dépendent de l'existence d'un agent alors que l'univers physique révélé par la science moderne se présente comme neutre et indépendant ${ }^{104}$. À cet égard, Taylor paraît osciller entre la thèse forte de la primauté ontologique du monde vécu et la posture plus modeste consistant à soutenir que tant que nous ne disposons pas véritablement d'une théorie objective de

100. Charles Taylor, "What's Wrong with Foundationalism?: Knowledge, Agency, and World", 2000, p. I20.

101. Charles Taylor (2002a), «Understanding the Other: a Gadamerian View on Conceptual Schemes", 20I Ia, p. 30-38; "And so we can be challenged by reality, or by the other; it can dawn on us that something does not fit, that we are not getting something important; and this can be the beginning of a process of revision" ("What's Wrong with Foundationalism ?: Knowledge, Agency, and World", 2000, p. I2I).

102. Charles Taylor, I989, p. 58-59. "How else to determine what is real or objective, or part of the furniture of things, than by seeing what properties or entities or features our best account of things has to invoke?" (Ibid., p. 68).

103. Ibid., p. 59.

104. "Of course, it is clear that an essential condition of the existence of such properties is that there are human beings in the world, with a certain form of life, and kinds of awareness, and certain patterns of caring. But these properties are no less real features of the world which does contain humans than any "neutral" properties are" (Ibid., p. 68). 
l'action et de la pensée humaines, rien ne justifie l'adoption de l'ontologie naturaliste selon laquelle les arrière-plans de l'expérience vécue seraient «moins réels» que la réalité dite «objective » ${ }^{105}$. Quoi qu'il en soit, le «tribunal de l'expérience» comporte jusqu'à preuve du contraire un ordre de significations interstitielles qui dépend de nous en tant qu'agents incarnés et situés tout en étant indépendant de notre volonté ou de nos choix: "These significances arise out of a combination of spontaneity and receptivity, constraint and striving; they are the ways the world must be taken in for a being defined by certain goals or needs to make sense of $i t^{106}$. " L'inspiration première de notre auteur est ici Heidegger, à qui reviendrait le mérite d'avoir indiqué une via media crédible entre le réalisme métaphysique traditionnel et le subjectivisme moderne: la "clairière » (clearing, Lichtung) présuppose un agent sans que celle-ci ne soit contrôlée ou intégralement configurée par celui-ci — «Dasein-related but not Dasein-centered ${ }^{107}$. Cette question de la transcendance dans l'immanence, qui constitue en fait l'un des thèmes centraux de la tradition phénoménologique depuis Husserl, consiste donc à se demander «[...] comment paradoxalement il y a pour nous de l'en-soi ${ }^{108}$.»

\section{Remarques conclusives}

Nous conclurons cette étude comparative par de brèves remarques en vue de mieux situer la contribution de Taylor au sein de la tradition herméneutique contemporaine. Tout d'abord, il est bien connu que la pierre angulaire de cette dernière est la célèbre "ontologisation du cercle herméneutique" opérée par Heidegger dans Être et temps (1927) et reprise par Gadamer dans Vérité et méthode (I960), c'est-à-dire la promotion de cette ancienne règle méthodologique au statut de structure fondamentale de l'existence humaine ${ }^{109}$. L'animale rationale est un être qui vit toujours-déjà au sein d'une compréhension préalable de son être et qui réfléchit sa situation en explicitant sa prise implicite sur le monde ainsi que ses possibilités d'être: "Il y a d'abord compréhension, puis son interprétation, où la compréhension en vient à se comprendre elle-même, à se saisir de ses anticipations ${ }^{110}$." À la fois "projet» (Entwurf) et "être-jeté»(Geworfenheit), la compréhension n'est plus alors conçue comme un mode spécifique de la connaissance humaine (aux côtés de l'explication ou de l'intuition), mais bien en tant que détermination essentielle de notre ouverture au monde, "forme d'accomplissement originaire du Dasein ${ }^{111}$.

105. Cf. Hubert L. Dreyfus, "Taylor’s (Anti-) Epistemology ", 2004, p. 63-79.

106. Ibid., p. 46.

107. Charles Taylor (I992), "Heidegger, Language, and Ecology ", I995, p. I I6.

108. Maurice Merleau-Ponty, I945, p. Ioo.

109. Cf. Martin Heidegger (I927), trad. I986, $\mathbb{3}$ I-32.

110. Jean Grondin, 2003, p. 38.

111. Gadamer, Hans-Georg (I960), trad. I996, p. 280. 
Comme le souligne Jean Grondin, cette thèse herméneutique ne suppose aucunement que l'on renonce à la conception classique de la vérité comme adaequatio rei et intellectus, car l'interprétation doit au contraire, en tant que "processus de révision constante", toujours "[...] se garantir contre l'arbitraire des idées reçues et diriger son regard sur les choses mêmes ${ }^{112}$ ». Nous sommes donc bien loin ici des herméneutiques antiréalistes qui rejettent la distinction entre l'ordre de nos interprétations et celui de la réalité (J. Derrida, M. Foucault, R. Rorty, G. Vattimo, etc.), ratifiant et radicalisant ainsi une certaine vulgate nietzschéenne et constructiviste: «[...] l'être se réduit aux interprétations que l'on en donne ${ }^{113}$ ». À l'inverse, affirmer le caractère "ontologique » du cercle herméneutique signifie qu'un contact direct avec le réel, voire une "fusion ${ }^{114}$ » de la pensée et de l'être, s'accomplit dans la relation inexorablement circulaire entre compréhension et interprétation. Gadamer critiquera ainsi le fondationnalisme postcartésien et son "préjugé contre les préjugés » en soutenant que notre historicité constitue une "condition positive» de l'être-au-monde et non «[...] une détermination limite de la raison et de sa prétention à saisir la véritéé15 ". Autrement dit, la compréhension humaine peut accéder aux choses mêmes non pas en dépit, mais bien en vertu de son appartenance linguistique et historique à la tradition: "Human knowing always depend on language and history, on a context of commitments and practices to show the thing itself in a certain way ${ }^{116}$."

La position de Taylor, telle que nous l'avons brièvement exposée dans ces pages, explore cette thèse audacieuse selon laquelle le cercle de la compréhension ouvre sur l'être des choses et propose en ce sens plusieurs pistes fécondes afin d'en préciser les enjeux. Premièrement, son modèle "ad hominem" vise à suggérer comment le progrès rationnel (ou la vérité) demeure concevable en ce qui concerne les normes les plus générales/profondes de l'action et de la pensée humaines: la raison disposerait de profondes ressources herméneutiques par-delà la sphère limitée et relative de la raison apodictique. Deuxièmement, sa discussion de la raison «immergée » rappelle que le cercle de la compréhension doit admettre une donation ori-

112. Jean Grondin, 2006, p. 55. En effet, selon Heidegger, la «tâche première, constante et ultime» de l'explicitation consiste "[...] non pas de se laisser pré-donner la pré-acquisition, la prévision et l'anti-cipation par des "intuitions" ou des concepts populaires, mais, en les élaborant, d'assurer toujours son thème scientifique à partir des choses mêmes" (Martin Heidegger (1927), trad. 1986, p. I33).

113. Jean Grondin, "La thèse de l'herméneutique sur l'être ", 2006, p. 47I.

114. Sur la métaphore de la "fusion» dans le contexte de la réflexion herméneutique, voir Jean Grondin, "La fusion des horizons. La version gadamérienne de l'adaequatio rei et intellectus?", 2005.

115. Hans-Georg Gadamer, I996, p. I00.

116. Brice Wachterhauser, "Gadamer's Realism: The "Belongingness" of Word and Reality", I994, p. I 54 . 
ginaire du monde dans l'expérience perceptive-pratique, soit une immersion antérieure à toute médiation linguistique, afin de maintenir ouvert cet "entre-deux" (Zwischen) entre l'être et la pensée qui constitue le lieu véritable de toute herméneutique "phénoménologique ${ }^{117}$. Troisièmement, ses analyses de la raison "située " mettent en relief la distinction entre les conditions causales de l'expérience et ses conditions d'intelligibilité (ou arrièreplans), de manière à éviter toute confusion entre les théories naturalistes du sujet connaissant, aussi complexes (holistiques, systémiques, cybernétiques, etc.) soient-elles, et sa perspective herméneutique sur les conditions et exigences de la compréhension. Quatrièmement, Taylor fait valoir contre le réalisme métaphysique traditionnel (ou les théories du logos ontique) l'énigme de l'expression - nous manifestons dans nos discours et nos actes un ordre de significations humaines qui ne préexiste pas à son incarnation dans nos vies - et inscrit en retour le tournant ontologique de l'herméneutique au sein de la révolution expressiviste initiée par Herder. Cinquièmement, la nature "passionnée» de la raison signifie que nous éprouvons inéluctablement le monde comme un «ordre moral» (moral order) pouvant faire l'objet d'une réflexion et d'un débat rationnels, plutôt que comme le support neutre et désenchanté de nos projections subjectives. Finalement, la notion de raison "substantielle " énonce un certain réalisme herméneutique (ou non problématique) voulant que nous demeurions toujours - c'est-àdire en-deçà de tout contrôle méthodique de l'expérience vécue - en prise sur la réalité, sans pour autant occulter ni la pluralité effective des perspectives et des traditions, ni le caractère essentiellement médiat des significations expressives qui façonnent nos vies.

Cela dit, nous pourrions faire ressortir de façon plus unitaire le projet philosophique de Taylor en soulignant que cette réflexion "méta-critique » sur les apories et illusions de la raison épistémologique vise en définitive à rendre possible un dialogue herméneutique sur le sens de la vie (ou autour de nos évaluations fortes). Ainsi, nous devrions tous convenir, selon notre auteur, qu'il existe une pluralité de positions - religieuses, non religieuses, anti-religieuses, humanistes, anti-humanistes, etc. - qui commandent le respect et sollicitent notre intelligence. Or ces positions divergentes ne pouvant être arbitrées par des arguments apodictiques (ou «knock-down arguments»), nous sommes appelés à étendre nos horizons de sympathie et de

117. Comme l'explique Gary B. Madison, nous devons d'abord admettre la donation de significations pré-linguistiques afin que puisse apparaître le sens véritable de la thèse de la « linguisticité " (Sprachlichkeit), qui consiste en l'affirmation de l'intelligibilité langagière ou de la "dicibilité » de l'être, et non en une forme d'idéalisme linguistique: "[the] thesis does not deny the meaningfulness of nonlinguistic modes of experience; rather, it affirms that meaningfulness by maintaining that such experience can always in principle be brought to expression (can be interpreted) in language" (Gary B. Madison, "The Interpretive Turn in Phenomenology: A Philosophical History ", 2004, p. 422). 
compréhension sur le mode d'un dialogue engagé, critique et ouvert ${ }^{118}$. Toute l'œuvre de Taylor a pour objectif de préparer et de promouvoir un tel effort de "clarification mutuelle» (mutual clarification) des ontologies ou identités morales. C'est dire que l'éthique de l'authenticité, bien comprise, est une éthique du dialogue authentique.

\section{Bibliographie}

Brague, Rémi. La Sagesse du monde. Histoire de l'expérience humaine de l'univers, Paris, Librairie Arthème Fayard, coll. Biblio essais, I999.

Dreyfus, Hubert L. «Taylor's (Anti-) Epistemology », dans R. Abbey (dir.), Contemporary Philosophy in Focus: Charles Taylor, Cambridge University Press, 2004 .

Gadamer, Hans-Georg. 1960. Vérité et Méthode. Les grandes lignes d'une herméneutique philosophique. Édition intégrale, Paris, Éditions du Seuil, trad. 1996.

- L'Art de comprendre. Écrits II, Herméneutique et champ de l'expérience humaine. Paris, Éditions Aubier Montaigne, I99I.

—. La philosophie herméneutique, Paris, Presses Universitaires de France, Épiméthée, 1996.

Grondin, Jean. L'universalité de l'herméneutique, Paris, Presses Universitaires de France, Épiméthée, I 993.

—. «La fusion des horizons. La version gadamérienne de l'adaequatio rei et intellectus?", Archives de philosophie, vol. 3, tome 68, 2005, p. 40I-4I 8 .

—. "La thèse de l'herméneutique sur l'être ", Revue de métaphysique et de morale, vol. 4, n 52, 2006, p. 469-48I.

Heidegger, Martin. 1927. Être et Temps, Paris, Éditions Gallimard, trad. 1986.

Madison, Gary B. «The Interpretive Turn in Phenomenology: A Philosophical History", dans Paul Fairfield (dir.), Working through Postmodernity. Essays in Honor of Gary Brent Madison, numéro spécial de Symposium, vol. 8, Hamilton, 2004, p. 397-467.

Merleau-Ponty, Maurice. Phénoménologie de la perception, Paris, Éditions Gallimard, coll. Tel, I945.

Polanyi, Michael. Personal Knowledge. Towards a Post-Critical Philosophy, The University of Chicago Press, 1958.

Taylor, Charles. Hegel, Cambridge, Cambridge University Press, 1977.

-. Human Agency and Language: Philosophical Papers 1, Cambridge University Press, 1985 a.

- Philosophy and the Human Sciences: Philosophical Papers 2, Cambridge University Press, $1985 \mathrm{~b}$.

- . Sources of the Self: The Making of the Modern Identity, Cambridge, Harvard University Press, 1989.

—. Philosophical Arguments, Cambridge, Harvard University Press, I995.

—. "Foundationalism and the Inner-Outer Distinction », dans Nicholas H. Smith (dir.), Reading McDowell: On Mind and World, Londres, Routledge, 2002.

__. «Rorty and Philosophy», dans Charles B. Guignon \& David R. Hiley, Richard Rorty, New York, Cambridge University Press, 2003.

118. Charles Taylor, "Afterword: Apologia pro Libro suo", 20Iо, p. 3 I 7. 
- «Ethics and Ontology», The Journal of Philosophy, vol. ı०o, n 6, 2003, p. 305-320

—. "Merleau-Ponty and the Epistemological Picture", dans Taylor Carman \& Mark B. N. Hansen (dir.), The Cambridge Companion to Merleau-Ponty, New York, Cambridge University Press, 2005.

—. "Précis de Modern Social Imaginaries ", Philosophiques, vol. 33, n² 2, 2006, p. $477-483$.

—. A Secular Age, Cambridge, Belknap Press of Harvard University Press, 2007.

—. "Reason and Its Adventures Since the Enlightenment ", Conférence Faith + Reason: A Dialogue at the Heart of Jesuit Education, Fordham Center on Religion and Culture, Fordham University, 2009.

—. "Charles Taylor Replies ", New Blackfriars, vol. 91, issue I036, 2010, p. 680698.

—. "Afterword: Apologia pro Libro suo", dans M. Warner, J. Vanantwerpen \& C. Calhoun (dir.), Varieties of Secularisms in a Secular Age, Harvard University Press, 2010, p. 300-32I.

- Dilemmas and Connections. Selected Essays, Cambridge et Londres, The Belknap Press of Harvard University Press, 20I Ia.

—. "Reason, Faith and Meaning", Faith and Philosophy, vol. 28, n ${ }^{\circ}$ I, 20I Ib, p. 5-I8.

—. "Recovering the Sacred", Inquiry: An Interdisciplinary Journal of Philosophy, vol. 54, $\mathrm{n}^{\circ}$ 2, 20 I Ic, p. I I 3-I 25.

- "Retrieving Realism", dans Mind, Reason, and Being-in-the-World. The McDowell-Dreyfus Debate, Joseph K. Schear (dir.), Londres et New York, Routledge, Taylor \& Francis Group, 2013.

Wachterhauser, Brice R. "Gadamer's Realism: The "Belongingness" of Word and Reality", dans Brice R. Wachterhauser (dir.), Hermeneutics and Truth, Evanston, Northwestern University Press, I994, p. I48-I7 I.

Will, Frederick L. Induction and Justification. An Investigation of Cartesian Procedure in the Philosophy of Knowledge, Londres, Cornell University Press, I974. 